\title{
Bio-Based Materials for the Italian Construction Industry: Buildings as Carbon Sponges
}

\author{
Olga Beatrice Carcassi, Enrico De Angelis, Giuliana Iannaccone, \\ Laura Elisabetta Malighetti, Gabriele Masera and Francesco Pittau
}

\begin{abstract}
This work brings together some recent research and results activities aiming at investigating the environmental benefits of using bio-based materials for the construction and refurbishment of residential buildings. The positive environmental effects of wood and other biogenic materials replacing other, more important, conventional ones, analysed through the application of Life Cycle Assessment methods, are here reported. Moreover, the investigated strategies for Carbon Capture and Storage (CCS) are here discussed, to evaluate the potential of carbon uptake of fast-growing biogenic materials when used as insulation systems. The results show the effectiveness of bio-based materials in contributing to the mitigation strategies of the impacts due to climate change.
\end{abstract}

Keywords Bio-based materials $\cdot$ Timber $\cdot$ Construction industry $\cdot$ Carbon storage $\cdot$ Life cycle assessment $\cdot$ Building retrofitting

\section{Introduction}

The construction sector plays a decisive role in the achievement of the European targets for the reduction of energy consumption (40\% of the total primary energy consumption) and carbon emissions (39\% of fossil-related emissions). With this aim, European and, consequently, Italian standards mainly addressed the decrease of the environmental impact during the use phase through the reduction of the demand for operating energy (European Commission 2010; Sartori and Hestnes 2007). As a consequence, the energy performance of buildings has been improved, mitigating the environmental impact deriving from the operation phase, but the importance of the other life cycle stages has increased because of the higher material input (Blengini

O. B. Carcassi $(\bowtie) \cdot$ E. De Angelis · G. Iannaccone · L. E. Malighetti · G. Masera Architecture, Built Environment and Construction Engineering-ABC Department, Politecnico di Milano, Milan, Italy

e-mail: olgabeatrice.carcassi@ polimi.it

F. Pittau

Department of Civil, Environmental and Geomatic Engineering, Institute of Construction \& Infrastructure Management-BAUG IBI, ETH Zürich, Zürich, Switzerland

(C) The Author(s) 2020

S. Della Torre et al. (eds.), Regeneration of the Built Environment

from a Circular Economy Perspective, Research for Development,

https://doi.org/10.1007/978-3-030-33256-3_23 
and Di Carlo 2010; Lavagna et al. 2018). As a matter of fact, the fossil carbon emitted by manufacturing of materials and construction might significantly affect the carbon saving from operational energy (Rovers 2014). The building material selection strongly affects the overall environmental impact of a building, especially the selection of the materials for the structural frame and the building envelope (i.e. basement, exterior walls and roof) on which the former has a major influence (Pal et al. 2017; Paleari et al. 2016).

The following work presents the results of some studies conducted with the aim of assessing the benefits, from the point of view of environmental impact, deriving from the use of bio-based materials as an alternative to conventional building materials for both new and existing buildings undergoing major renovations.

\section{Timber in the Italian Construction Industry}

The consumption of forest products has increased in all European regions in the last 20 years, partly supported by public policies which encouraged the use of wood in the construction and renovation sector through the implementation of energy efficiency policies (Martín Vallejo 2015).

Reduced times for construction, combined with high-performance expectations, increased the interest towards prefabricated construction systems. Among these, wood-based preassembled components are those accounting for the largest growth in the Italian market, with approximately $2.8 \%$ of the housing assets and $8.5 \%$ of the total building stock (Pittau et al. 2016). The picture provided by Centro Studi FederlegnoArredo in their report 'Rapporto case ed edifici in legno' suggests a countertrend with respect to the total amount of investments in the construction industry: starting from 2010, more than 3,000 timber buildings have been built, $89 \%$ of which are residential (Gardino 2015). Between 2006 and 2010, the number of wooden houses rose fivefold and increased by $50 \%$ within 2015 , while the use of other construction materials decreased by $40 \%$ between 2006 and 2010 and has increased of $30 \%$ within 2015 . Italy is the fourth European player in the wooden building sector, overcoming countries with an ancient timber construction tradition such as Austria, Finland, France and the Netherlands. The highest concentration of timber construction industries is in Lombardy, followed by Veneto, Emilia Romagna and Trentino Alto Adige.

The benefits in using preassembled timber components for building constructions are manifold: the manufacturing costs can be significantly decreased by the seriality and modularity of the production, while the rapidity of assembly ensures a short duration of the onsite construction, without decreasing the structural stiffness and the thermo-acoustic performances. Moreover, generally, prefabricated construction technologies allow the optimization of the manufacturing process, as well as decreasing fossil-carbon emissions during material processing and assembly.

Modular timber constructions, especially if based on massive wooden elements (e.g. plywood, LVL panels, cross-laminated timber (CLT), etc.), also allow the storage 
of a large amount of carbon into the structure (roughly $50 \%$ of the mass) (Villa et al. 2012).

The use of these construction technologies can provide several positive benefits both in new buildings and in the refurbishment and retrofit of existing ones.

\subsection{Timber in New Buildings}

With respect to other structural traditional materials, e.g. concrete, the use of wood for construction generally results in lower energy intensity and fossil-carbon emission (Gustavsson and Sathre 2006). Moreover, the Italian market is rapidly changing due to a renewed interest in wood-based products and their outstanding mechanical properties. Italian market is also supported by industries that, following this new environmental trend, try to reach a local production by concentrating manufacturing, as far as possible, in their own country. Since timber-framed panels are a valid prefabricated solution, their request for new construction has been constantly increasing in the last ten years (Confindustria 2018).

For the production of wooden products, energy for drying, cutting, drilling and planning is the only resource used: in this scenario, the energy balance for a wooden building becomes particularly sustainable.

The results of a Life Cycle Assessment (LCA), from-cradle-to-gate, of a CLT panel produced in Italy supported this thesis. This stimulates the exploitation of wood and forests to create regenerative building products which promote a sustainable management of the natural environment (Villa et al. 2012).

\subsection{1 $\mathrm{CO}_{2}-$ Wood in Carbon Efficient Construction}

'Wood in carbon efficient construction' was a research project, coordinated by Aalto University, focused on the demonstration of the positive effects on climate of using wood in construction. The findings are the result of a large transnational European research project involving twenty organizations from five countries: Austria, Finland, Germany, Italy and Sweden. Even if the current normative policy framework in these emerging matters is still under development, the findings of $\mathrm{CO}_{2}$ scientifically prove that there are convincing advantages and potentials for using wood in construction to mitigate climate change, whereas the forests are managed so as to maintain or increase forest carbon stocks (Fig. 1).

The research filled in some knowledge gaps by applying advanced methods for determining the carbon footprint of wooden buildings during their full life cycles. A carbon footprint analysis of wooden buildings is more complex than that of many other products, due to the dynamics of forest growth and the variety of byproducts generated. From a life cycle perspective, the environmental impact of wood is strongly dependent on the management of forest and end-of-life (EoL) scenarios. In LCA, assuming the forest system and the use of residues and related benefits as 

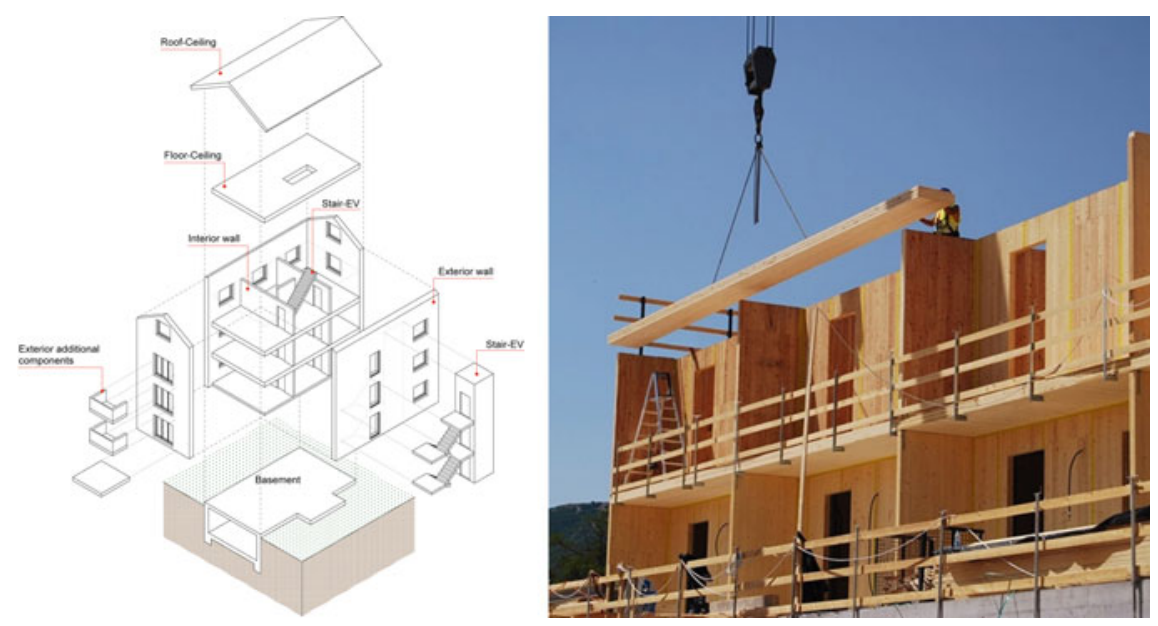

Fig. 1 An Italian case-study in the $\mathrm{CO}_{2}$ project: Progetto CASE L'Aquila (Luigi Fragola \& Partners, Studio Legnopiù srl). Axonometric view (left); onsite CLT assembly (right)

separated systems allows to make wood building and timber products comparable to alternative building materials, i.e. as concrete, steel, etc.

A long-term sustainable forest management as well as an efficient use of primary resources from premium quality (e.g. laminated wood, plywood, timber frame construction) is fundamental conditions to achieve sustainability goals.

In the early design process of timber construction, the deconstruction, reuse and recycling of the products has to be considered too. Besides the results of LCA, other aspects should be considered as relevant to the choice of bio-based products for buildings: reduced operational complexity, total prefabrication with reduced production complexity, integration, lightness, energy efficiency, good seismic and fire performances, easy assembly and disassembly on site, etc. (Kuittinen et al. 2013).

\subsection{Timber for Existing Buildings}

The renovation and the energy retrofit of existing buildings is becoming a fundamental task for the construction sector in next future. According to recent market surveys, in Europe, nowadays roughly $50 \%$ of economic activities of the construction sector are strictly related to refurbishment (Juan et al. 2009).

The energy improvement of the building stock realized in the last 50 years, mostly represented by poorly insulated buildings with obsolete heating systems, is an urgent mission in order to meet the goal of a significant reduction of greenhouse gas (GHG) emissions and energy consumption. In the EU, the building sector is responsible for roughly $40 \%$ of the total primary energy consumption, $63 \%$ of which depends on the residential sector alone (Eurostat 2016). 

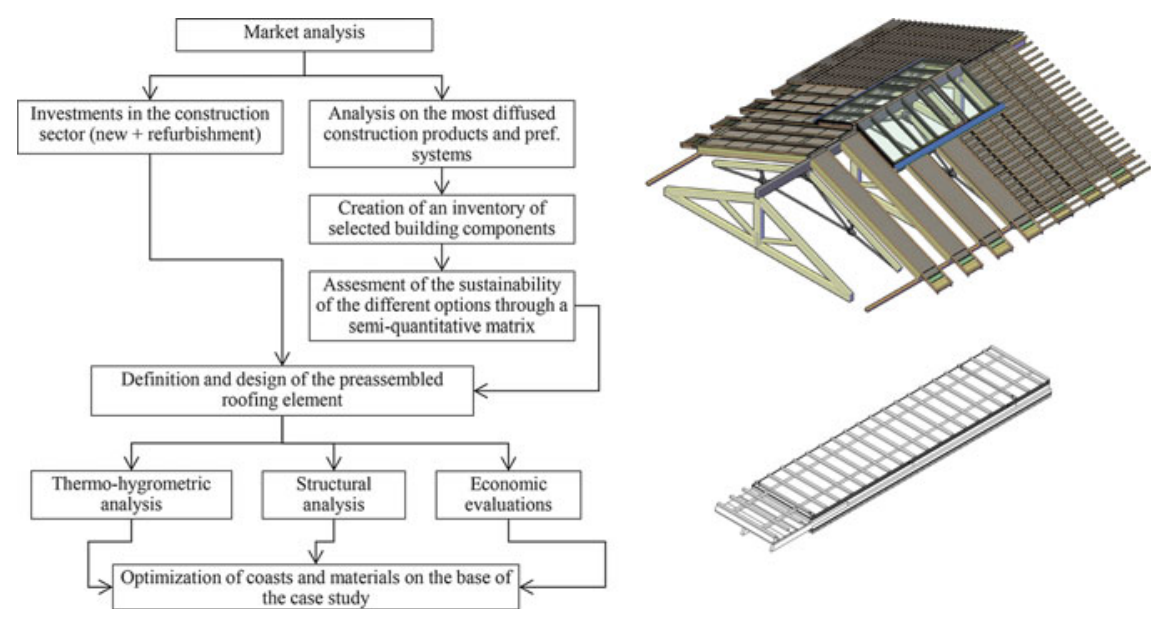

Fig. 2 Structure of the working activities for the development of the preassembled roofing component (left). Substitution of an existing roof with the HABITAT preassembled timber panels (top right) and a single module of HABITAT panel (bottom right)

Considering the EU target of reduction of energy consumption ( $-20 \%$ by 2020 and $-27 \%$ by 2030 ), the retrofit of existing façades is an urgent issue that should be solved rapidly in order to reduce the energy need from buildings, increase the indoor comfort and the aesthetics of the facades, that very often requires a deep renovation (Passer et al. 2016; Meijer et al. 2009).

Prefabricated elements are a valid solution to accelerate the renovation process at a large scale, since the duration of onsite installation is faster compared to traditional construction solutions and the integration of all components facilitates quality control during the offsite assembly with a reduced risk of performance failure during the service life (Ramage et al. 2017). Timber-based prefabricated solutions for envelope retrofitting add incremental benefits at different levels, as demonstrated in the following examples.

\subsubsection{Habitat}

The habitat research project aimed at the development of a prefabricated panel for roof renovation, made of a timber structure with a high content of recycled material. The modular panels were designed to be produced by underprivileged employees of social cooperatives (type B, according to the Italian regulations) located in northern Italy. The component is the final result of a consulting activity for a consortium of social cooperatives (Consorzio Consolida) funded by Fondazione della Provincia di Lecco Onlus. 
The methodology for the development of the prefabricated building component was structured in different working steps, as shown schematically in Fig. 2 on the left.

The work included the different analyses for the definition of the main characteristics of the preassembled building component, based on the market potential and the needs and constraints of the social cooperatives, main partners of the research project.

In the first phase, a survey of the most common building products with a high recycled content commonly used in building renovations was carried out in order to provide recommendations for the following design steps. For each selected product, the environmental sustainability and economic costs were investigated on the bases of a semi-quantitative evaluation matrix, which took into account the following four categories (Pittau et al. 2017):

A. Supply chain - which includes the distance of the manufacturing process (from raw materials extraction to final production), the annual amount of production and the annual variability;

B. Sustainability - which includes the amount of recycled materials used for production, the share of material which can be recycled at the end of life (EOL), the embodied energy for extraction and manufacturing and the energy need for product disposal at the EoL;

C. Economic cost-which includes the cost of material supply and the cost of production, divided into automation of production, time needed for a complete production cycle (from transportation to manufacturing to packaging), cost related to the manufacturing area and cost related to the storage;

D. Usage-which includes the physical characteristics, divided into durability, vapour permeability, safety; the reversibility of use, the adaptability to refurbishment and, finally, the innovation value. Based on the results of the evaluation matrix, the concept design of the technical element was implemented: a wood-based composite panel with a high recycled content to be installed on the existing structures (Fig. 2 on the right).

The project demonstrated that, if the dimension and shape of the panels are optimized, the use of an advanced prefabrication system for the renovation of the existing roof is a competitive choice, with a cost which is very close to the cost of a traditional construction system. Moreover, both the quality and reliability of the renovation can significantly increase, since a better control of the whole building process is ensured at every single stage, from manufacturing to post-construction. 


\section{Bio-Based Materials for Insulation: The Building Envelope as a Carbon Sponge}

Considering the increasing social emphasis on environmental issues, waste disposal and the depletion of raw materials, bio-based materials constitute a promising alternative to those obtained from fossil carbon. Fast-growing biogenic materials, e.g. straw or hemp shives, are highly promising alternatives for insulation, since their thermal conductivity is generally low, and they can be locally available (Garas et al. 2009). Moreover, the use of by-products of the food industry, like straw in particular, is highly beneficial from an environmental prospective, since it can be considered as a by-product of the food industry. Thus, no land competition issues are expected if straw is largely used as construction material in replacement of conventional nonbiogenic materials. Actually, straw can be considered mostly as a waste, since only $7 \%$ of the total production is sold as product — mainly as animal litter — and its use in construction is a valuable contribute which allows to close the cycle and decrease the production intensity of construction materials and the depletion of virgin resources (Eurostat 2017).

During their growth, biogenic materials uptake carbon dioxide through photosynthesis, with a percentage that generally can be assumed as $50 \%$ of the dry mass. Contrarily to timber, which takes longer to be fully regenerated in the forest after harvesting, straw requires much less time to be regenerated since after just some months, the vegetal mass harvested can be fully regenerated in the cropland. This fast regeneration leads to a higher regenerative capacity since the biogenic $\mathrm{CO}_{2}$ that will be released after the EoL of the building will be fully compensated by the $\mathrm{CO}_{2}$ absorbed in the crop (Levasseur et al. 2012; Guest et al. 2013).

It is estimated that up to $150 \mathrm{Mt}$ of $\mathrm{CO}_{2}$ can be stored in existing facades in Italy (Ballarini et al. 2014). Thus, building facades can be seen as Carbon Capture and Storage (CCS) systems when the carbon is effectively massively stored in biogenic products (structural elements, but especially insulation) and fast captured in crops. This CCS system, if largely used in construction, can give a significant contribution to mitigate climate change and achieve the Paris Agreement objectives.

\subsection{Evaluation of Carbon Uptake Benefits Through a Dynamic Life Cycle Assessment (DLCA)}

In the next decades, a large share of residential buildings in the EU-28 is expected to be renovated, and a large amount of insulation materials will be produced. But, when the primary energy requirements of the buildings are reduced after retrofitting, the contribution to carbon emissions due the production of insulation materials increases. The objective of this study, developed together with the chair of Sustainable Construction of ETH Zurich, was to assess the contribution to climate change mitigation of carbon storage potential in different biogenic insulation alternatives when used 
for the energy retrofitting of existing facades. Five alternative construction solutions for the renovation of the exterior walls were taken as reference: I-joint frame with pressed straw (STR), preassembled frame with injected hempcrete (HCF), timber frame (TIF), hempcrete blocks (HCB) and expanded polystyrene for external thermal insulation composite system (EPS).

In particular, in order to properly consider the amount of carbon stored in products, a dynamic life cycle assessment (DLCA) was introduced to verify the contribution of different bio-based materials on the radiative forcing over time, which contributes to restore the radiative balance of the Earth.

In fact, the lack of time dependence and the treatment of the biogenic $\mathrm{CO}_{2}$ are critical aspects in LCA and carbon footprint calculations, whereas the dynamic LCA calculation model proposed by Levasseur et al. (Levasseur et al. 2010) allows to take into account carbon uptake and GHG emissions over time. The instantaneous radiative forcing and consequently the dynamic GWP (GWPdyn), were calculated for each wall alternative and for the three disposal scenario (DS) through a DLCA calculation model (Pittau et al. 2019). The values are shown in Fig. 3.

The results show that only bio-based materials with a very fast regrowth, e.g. straw, have an effective potential in removing carbon from the air in a very short time and can contribute to achieve the Paris Agreement goals by 2050.

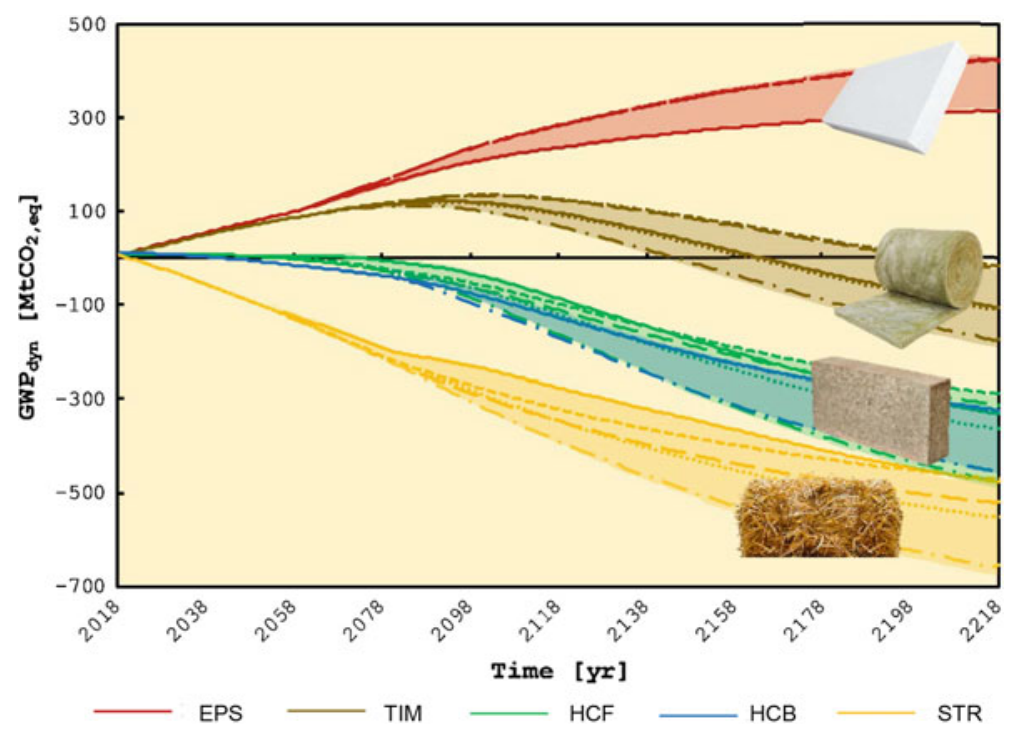

Fig. 3 Scenarios of carbon mitigation of the construction sector due to the renovation of the European residential building stock 


\section{Conclusion}

Achieving the decarbonization targets by 2050 as set by the European Union requires the adoption of several measures. The only reduction of primary energy requirements for both new and existing building is not effective, as the contribution of the production of insulation materials to carbon emissions increases.

A viable strategy could be the introduction of carbon capture and storage systems so to benefit from the long-term carbon storage in the building stock.

The combination of prefabrication with sustainable bio-based building materials, if extended on a large scale, could offer several benefits at different levels.

While the sustainability of wood as a building material is a complex issue, as its environmental impact is strongly related to forest management and end-of-life scenarios, fast-growing bio-based materials are a valuable alternative to insulate the buildings, as the biogenic carbon can be stored in the built environment for a relatively long time. However, this benefit is irrelevant when compared to the total emissions deriving from the use of existing buildings. Therefore, in order to accelerate the transition and meet the carbon budget limits required by 2050 , it is necessary to increase the renovation rate of buildings in Europe. In fact, only with a drastic acceleration of the energy renovation of buildings, it would be possible to generate a significant benefit due to the carbon storage in the building stock.

\section{References}

Ballarini, I., Corgnati, S. P., \& Corrado, V. (2014). Use of reference buildings to assess the energy saving potentials of the residential building stock: The experience of TABULA project. Energy Policy, 68, 273-284. https://doi.org/10.1016/j.enpol.2014.01.027.

Blengini, Gian Andrea, \& Di Carlo, Tiziana. (2010). The changing role of life cycle phases, subsystems and materials in the LCA of low energy buildings. Energy and Buildings, 42(6), 869-880. https://doi.org/10.1016/j.enbuild.2009.12.009.

Confindustria. (2018). IL SETTORE DELL'INDUSTRIA DEL LEGNO NEI TERRITORI DI LECCO E SONDRIO.

European Commission. (2010). Directive 2010/31/EU. Official Journal of the European Union, $13-35$.

Eurostat. 2017. Main Annual Crop Statistic.

Garas, G, Allam, M., \& Dessuky, R. E. (2009). Straw bale construction as an economic environmental building alternative- a case study. Journal of Engineering and Applied Sciences, 4(9), 54-59. https://www.scopus.com/inward/record.uri?eid=2-s2.0-78650023657\&partnerID= 40\&md5=05a84deba2193e23490e891f68179986.

Gardino, P. (2015). Il Mercato Italiano Delle Case in Legno Nel 2010.

Guest, G., Bright, R. M., Cherubini, F., \& Strømman, A. H. (2013). Consistent quantification of climate impacts due to biogenic carbon storage across a range of bio-product systems. Environmental Impact Assessment Review, 43(November), 21-30. https://doi.org/10.1016/j.eiar.2013.05.002.

Gustavsson, Leif, \& Sathre, Roger. (2006). Variability in energy and carbon dioxide balances of wood and concrete building materials. Building and Environment, 41, 940-951. https://doi.org/ 10.1016/j.buildenv.2005.04.008. 
Juan, Yi K., Perng, Yeng Horng, Castro-Lacouture, Daniel, \& Kuo Sheng, Lu. (2009). Housing refurbishment contractors selection based on a hybrid fuzzy-QFD approach. Automation in Construction, 18(2), 139-144. https://doi.org/10.1016/j.autcon.2008.06.001.

Kuittinen, M., Alice, L., \& Gerhard, W. (2013). Wood in carbon efficient construction. Tools, methods and applications. Wood in Carbon Efficient Construction. Tools, Methods and Applications, 78-150. http://issuu.com/eco2book/docs/eco2_book.

Lavagna, M., \& Serenella, S. (2018) Impatti Ambientali LCA Del Patrimonio Residenziale Europeo e Scenari Di Prevenzione, 291-98. https://doi.org/10.13128/Techne-22113.

Levasseur, A., Lesage, P., Margni, M., \& Samson, R. (2012). Biogenic carbon and temporary storage addressed with dynamic life cycle assessment. Journal of Industrial Ecology, 17(1), 117-128. https://doi.org/10.1111/j.1530-9290.2012.00503.x.

Levasseur, A., Pascal L., Manuele M., Louise D., \& Réjean, S. (2010). Considering time in LCA: Dynamic LCA and its application to global warming impact assessments. Environmetal, Science \& Technology, 44. https://doi.org/10.1021/es9030003.

Martín, V., \& Myriàm. (2015). State of Europe's forests 2015. State of Europe's forests 2015. Madrid.

Meijer, Frits, Itard, Laure, \& Sunikka-Blank, Minna. (2009). Comparing European residential building stocks: Performance, renovation and policy opportunities. Building Research and Information, 37(5-6), 533-551. https://doi.org/10.1080/09613210903189376.

Eurostat. (2016). Final energy consumption by sector. Online at:https://ec.europa.eu/eurostat/ databrowser/view/ten00124/default/table?lang=en. Accessed 24 October 2019

Pal, S. K., Takano, A., Alanne, K., Palonen, M., \& Siren, K. (2017). A multi-objective life cycle approach for optimal building design: A case study in finnish context. Journal of Cleaner Production, 143, 1021-1035. https://doi.org/10.1016/j.jclepro.2016.12.018.

Paleari, Michele, Lavagna, Monica, \& Campioli, Andrea. (2016). The assessment of the relevance of building components and life phases for the environmental profile of nearly zero-energy buildings: Life cycle assessment of a multifamily building in Italy. International Journal of Life Cycle Assessment, 21(12), 1667-1690. https://doi.org/10.1007/s11367-016-1133-6.

Passer, A., Ouellet-Plamondon, C., Kenneally, P., John, V., \& Habert, G. (2016). The impact of future scenarios on building refurbishment strategies towards plus energy buildings. Energy and Buildings, 124, 153-163. https://doi.org/10.1016/j.enbuild.2016.04.008.

Pittau, F., Malighetti, L. E., Masera, G., \& Lannaccone, G. (2016). A new modular preassembled timber panel for the energy retrofit of the housing stock. In WCTE 2016-World Conference on Timber Engineering.

Pittau, F., Lumia, G., Heeren, N., Iannaccone, G., \& Habert, G. (2019). Retrofit as a carbon sink: The carbon storage potentials of the EU housing stock. Journal of Cleaner Production, 214(March), 365-376. https://doi.org/10.1016/j.jclepro.2018.12.304.

Pittau, F., Malighetti, L. E., Iannaccone, G., \& Masera, G. (2017). Prefabrication as large-scale efficient strategy for the energy retrofit of the housing stock: An Italian case study. Procedia Engineering, 180, 1160-1169. https://doi.org/10.1016/j.proeng.2017.04.276.

Ramage, M. H., Henry, B., Marta, B.-W., George, F., Thomas, R., Darshil, U. S., et al. (2017). The wood from the trees: The use of timber in construction. Renewable and Sustainable Energy Reviews, 68, 333-359. https://doi.org/10.1016/j.rser.2016.09.107.

Rovers, R. (2014). Zero-energy and beyond: A paradigm shift in assessment. Buildings, 5(1), 1-13. https://doi.org/10.3390/buildings5010001.

Sartori, I., \& Hestnes, A. G. (2007). Energy use in the life cycle of conventional and low-energy buildings: A review article. Energy and Buildings, 39(3), 249-257. https://doi.org/10.1016/j. enbuild.2006.07.001.

Villa, N., Pittau, F., De Angelis, E., Iannaccone, G., Dotelli, G., \& Zampori, L. (2012). Wood products for the italian construction industry-an LCA-based sustainability evaluation. Proceeding of WCTE, 2012(5), 609-613. 
Open Access This chapter is licensed under the terms of the Creative Commons Attribution 4.0 International License (http://creativecommons.org/licenses/by/4.0/), which permits use, sharing, adaptation, distribution and reproduction in any medium or format, as long as you give appropriate credit to the original author(s) and the source, provide a link to the Creative Commons license and indicate if changes were made.

The images or other third party material in this chapter are included in the chapter's Creative Commons license, unless indicated otherwise in a credit line to the material. If material is not included in the chapter's Creative Commons license and your intended use is not permitted by statutory regulation or exceeds the permitted use, you will need to obtain permission directly from the copyright holder.

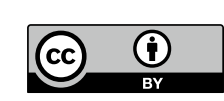

